\title{
THE EFFECTIVENESS OF THE HEALTH SYSTEM IN SERBIA IN 2014 AND 2015 AND MENTAL HEALTH CARE INDICATORS
}

The World Health Organization emphasized the importance of mental health by including it in their definition of health as "a state of complete physical, mental and social well-being and not merely the absence of disease or infirmity." Mental health has direct influence to the quality of life of citizens as well as to productivity of economy. Therefore, both government and enterprises are interested for further improvement in this field. The European Health Consumer Index (EHCI) was founded as a project in 2006, and it has been working ever since on comparison and ranking of the health systems of the European countries. Its main aim is the setting of standards for well-functioning and organization of health care from the perspective of patients (consumers) - users of the health system. Assessment of the health system is based on pre-determined forty eight indicators, divided into six groups. The aim of this study was to assess the state of Serbian mental health care in 2014 and 2015 from the perspective of European health consumer index and propose recommendations for its improvement and functioning in accordance with the norms of European standards. The Republic of Serbia, according to the European Health Consumer Index, was ranked 33rd. in 2014 among European countries, with 473 points, while in 2015 was ranked 30 with 554 points. Mental health care indicators shows improvement in 2015 comparing with 2014. year.

Keywords: Health system, European Health Consumer Index, Mental health care

* M.D., Assistant Director at Institut of Public Health of Serbia "Milan Jovanović-Batut", e-mail: perisa.simonovic@gmail.com

** M.D., Assistant Professor at Dental University Pančevo and Institut of Public Health of Serbia "Milan Jovanović-Batut", e-mail:mima_gajic@batut.org.rs

*** Mr, Assistant General at "Health monitor", NGO 


\section{INTRODUCTION}

The World Health Organization emphasized the importance of mental health by including it in their definition of health as "a state of complete physical, mental and social well-being and not merely the absence of disease or infirmity."

The European Health Consumer Index (EHCI) was founded as a project in 2006, and it has been working ever since on comparison and ranking of the health systems of the European countries. Its main aim is the setting of standards for well-functioning and organization of health care from the perspective of patients (consumers) - users of the health system. Assessment of the health system is based on pre-determined forty eight indicators, divided into six groups. Mental health care in Serbia in this study will be assesed through mental health care indicators defined by EHCI. In 2014 and 2015 there were 36 countries included in EHCI estimation, among them was the Republic of Serbia. ${ }^{2}$

\section{THE AIM}

The aim of this study was to assess the state of Serbian mental health care in 2014 and 2015 from the perspective of European health consumer index and propose recommendations for its improvement and functioning in accordance with the norms of European standards.

\section{RESULTS}

\subsection{Indicators of the Health Care System Efficiency}

Health care system assessment was made on the basis of pre-determined forty-eight indicators, divided into six following groups:

- The first group included indicators that describe the awareness of patients and their rights;

- The second group of indicators assessed the availability of health care (waiting times for the treatment);

- The third group of indicators evaluated the outcomes of the treatment;

- The fourth group observed the range and scope of services provided in health care;

- The fifth group assessed prevention;

- The sixth group assessed use of pharmaceuticals.

WHO (2016): “Mental Health: A State of Well-being“, Retrieved May 7, 2016.

2 Björnberg Arne, Hjertqvist Johan (2015): "Euro Health Consumer Index 2014 Report", Health Consumer Powerhouse, 27.01.2015 
Ranking of countries was based on the calculated indicators, where the highest score for a given indicator was 3 and the lowest 1 . The scoring points were multiplied by a coefficient determined for each group of indicators, so that the total sum amounted $1000 .^{3}$ The score in each individual group is shown in the Table 1.

Table 1. Relative weight of the six observed groups presented in scores

\begin{tabular}{|l|c|}
\hline Group: & Maximum scores \\
\hline Group 1.- Patient rights and information & 150 \\
\hline Group 2.- Accessibility of health care & 225 \\
\hline Group 3.- Outcomes of the treatment & 250 \\
\hline Group 4.- Range and reach of services & 150 \\
\hline Group 5.- Prevention & 125 \\
\hline Group 6.- Pharmaceuticals & 100 \\
\hline Total & 1000 \\
\hline
\end{tabular}

This study compared the health care system of the Republic of Serbia and its mental health indicators with health care systems of the neighbouring countries (Croatia, Montenegro, Macedonia, Bulgaria, Albania and Slovenia) in 2014 and $2015^{4,5,6,7}$

Group 1. - Patients' rights and their awareness were evaluated by the following indicators:

1) Healthcare law based on Patients' Rights

2) Patient organisations involved in decision making

3) No-fault malpractice insurance

4) Right to second opinion

5) Access to own medical record

6) Registry of bona fide doctors

7) Web or 24/7 telephones HC info with interactivity

8) Cross-border care financed from home

9) Provider catalogue with quality ranking

10) EPR penetration

11) Patients' access to on-line booking of appointments?

12) e-prescriptions

$3 \quad$ Björnberg Arne, Hjertqvist Johan (2016): "Euro Health Consumer Index 2015 Report", Health Consumer Powerhouse, 26.01.2016

4 WHO (2014): "European Health for All database“ (HFA-DB), Copenhagen,WHO Regional Office for Europe; 2014

WHO: http: http://www.who.int/nha/en/

Eurostat: http://epp.eurostat.ec.europa.eu; 2014

Internet, www.corporatehealthgroup.com 
In connection to the rights of patients and their awareness, the highest score in 2014 as well as in 2015 was achieved by FYR Macedonia.

Table 2. Patient rights and their awareness in 2014 and 2015

\begin{tabular}{|c|c|c|c|c|c|c|c|c|c|c|c|c|c|c|}
\hline INDICATOR & 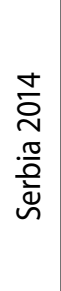 & 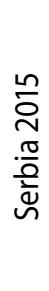 & 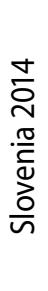 & 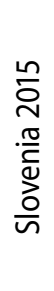 & 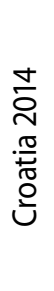 & 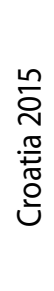 & 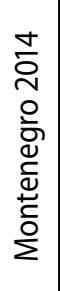 & 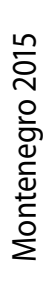 & 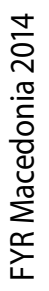 & 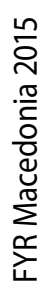 & 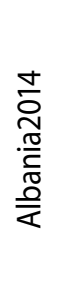 & 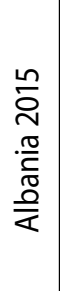 & 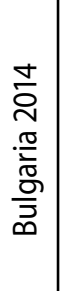 & 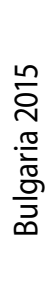 \\
\hline $\begin{array}{l}\text { Healthcare law based on } \\
\text { Patients' Rights }\end{array}$ & 3 & 3 & 3 & 3 & 3 & 3 & 2 & 2 & 3 & 3 & 3 & 3 & 1 & 1 \\
\hline $\begin{array}{l}\text { Patient organisation } \\
\text { involvement }\end{array}$ & 2 & 2 & 2 & 3 & 2 & 3 & 1 & 2 & 3 & 3 & 3 & 1 & 3 & 3 \\
\hline $\begin{array}{l}\text { No-fault malpractice } \\
\text { insurance }\end{array}$ & 2 & 2 & 2 & 2 & 1 & 1 & 2 & 2 & 2 & 2 & 1 & 1 & 1 & 1 \\
\hline Right to second opinion & 2 & 3 & 2 & 2 & 3 & 3 & 3 & 3 & 3 & 3 & 2 & 3 & 1 & 1 \\
\hline $\begin{array}{l}\text { Access to own medical } \\
\text { record }\end{array}$ & 2 & 3 & 2 & 3 & 2 & 2 & 3 & 3 & 3 & 3 & 3 & 3 & 2 & 3 \\
\hline $\begin{array}{l}\text { Registry of bona fide } \\
\text { doctors }\end{array}$ & 1 & 3 & 2 & 2 & 2 & 3 & 1 & 1 & 3 & 3 & 3 & 3 & 2 & 1 \\
\hline $\begin{array}{l}\text { Web or } 24 / 7 \text { telephone } \\
\text { HC info }\end{array}$ & 2 & 3 & 2 & 2 & 1 & 3 & 2 & 1 & 3 & 3 & 1 & 1 & 1 & 1 \\
\hline $\begin{array}{l}\text { Cross-border care seeking } \\
\text { freely allowed }\end{array}$ & 2 & 2 & 1 & 3 & 1 & 2 & 2 & 2 & 2 & 2 & 2 & 2 & 1 & 1 \\
\hline $\begin{array}{l}\text { Provider catalogue with } \\
\text { quality ranking }\end{array}$ & 1 & 1 & 1 & 1 & 1 & 2 & 1 & 1 & 2 & 3 & 1 & 1 & 1 & 1 \\
\hline EPR penetration & 1 & 1 & 2 & 2 & 3 & 3 & 2 & 2 & 3 & 3 & 1 & 1 & 3 & 3 \\
\hline $\begin{array}{l}\text { On-line booking of } \\
\text { appointments? }\end{array}$ & 1 & 1 & 3 & 3 & 3 & 3 & 1 & 1 & 3 & 3 & 1 & 1 & 1 & 1 \\
\hline e-prescriptions & 1 & 1 & 1 & 3 & 3 & 3 & 1 & 1 & 3 & 3 & 1 & 1 & 1 & 1 \\
\hline Total score & 20 & 25 & 23 & 29 & 25 & 31 & 21 & 21 & 33 & 34 & 22 & 21 & 18 & 18 \\
\hline
\end{tabular}

Legend:1. weak; 2. good or uncomparable; 3 . great

Table 2 shows that out of the countries in the region, only Macedonia achieved excellent results in most indicators about rights and patients' awareness. 
Serbia showed low score (20 points) in 2014, but in 2015 made progress and reach 25 points, which could be concluded as a move to the right direction. However, there is still room for improvement in:

- $\quad$ patients' involvement in health policy through raising their awareness

- $\quad$ establishing a catalog-ranked health providers

- $\quad$ accessing to electronic patient record at the entire territory, provide phone scheduled appointments to physicians and availability of electronic prescriptions.

Surprisingly, Albania has reduced involvement of patient organizations in health policy, Montenegro has diminished availability of Web or 24/7 telephone $\mathrm{HC}$ info and Bulgaria has lost Registry of bona fide doctors.

Group 2. - Accessibility of health care (waiting fortreatment) was assessed by the following indicators:

1) Family doctor same day access

2) Direct access to Specialist

3) CT scan $<7$ days

4) A\&E waiting time for a visit to the Accident and Emergencies department of a hospital

Table 3. Accessibility (waiting times for treatment) in 2014 and 2015

\begin{tabular}{|c|c|c|c|c|c|c|c|c|c|c|c|c|c|c|}
\hline INDICATOR & 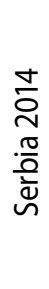 & 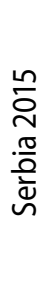 & 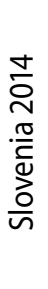 & 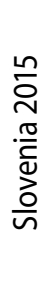 & 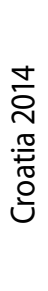 & 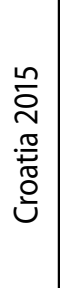 & 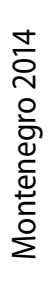 & 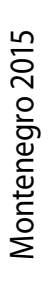 & 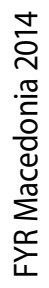 & 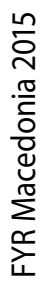 & 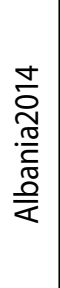 & 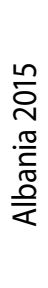 & 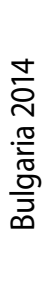 & 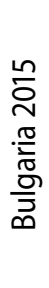 \\
\hline $\begin{array}{l}\text { Family doctor same day } \\
\text { access }\end{array}$ & 3 & 3 & 2 & 2 & 3 & 3 & 2 & 2 & 3 & 3 & 3 & 3 & 3 & 3 \\
\hline Direct access to specialist & 1 & 2 & 2 & 2 & 2 & 3 & 1 & 1 & 2 & 2 & 3 & 1 & 2 & 1 \\
\hline CT scan $<7$ days & 1 & 1 & 1 & 1 & 1 & 1 & 1 & 1 & 3 & 3 & 2 & 2 & 1 & 2 \\
\hline A\&E waiting times & 2 & 3 & 2 & 2 & 3 & 3 & 3 & 3 & 3 & 3 & 3 & 3 & 2 & 2 \\
\hline Total score & 7 & 9 & 7 & 7 & 9 & 10 & 7 & 7 & 11 & 11 & 11 & 9 & 8 & 8 \\
\hline
\end{tabular}

Legend:1. weak; 2. good or uncomparable; 3. great 
As it can be seen from Table 3, Macedonia achieved the highest score in assessing the availability of health services in 2014 and in 2015 with stable 11 points.

Serbia and Slovenia with seven points were the weakest with availability of health services in 2014, but in 2015 Serbia achieved nine points, which make Serbia even better then Slovenia(7), Montenegro (7) and Bulgaria (8), in 2015, but still weaker than Croatia (10) and Albania (11).

In 2015 Serbia improved patients access to specialist and reduced waiting time for a visit to the Accident and Emergencies department of a hospital.

In order for Serbian health services to become more accessible, it is necessary to work on improvement of availability of necessary diagnostic, operational procedures and therapy.

Group 3. - Outcomes of the treatment The third set of indicators evaluated treatmentoutcomes through the following indicator:

1) Depression

Table 4. Treatment outcomes in 2014 and 2015 for depression

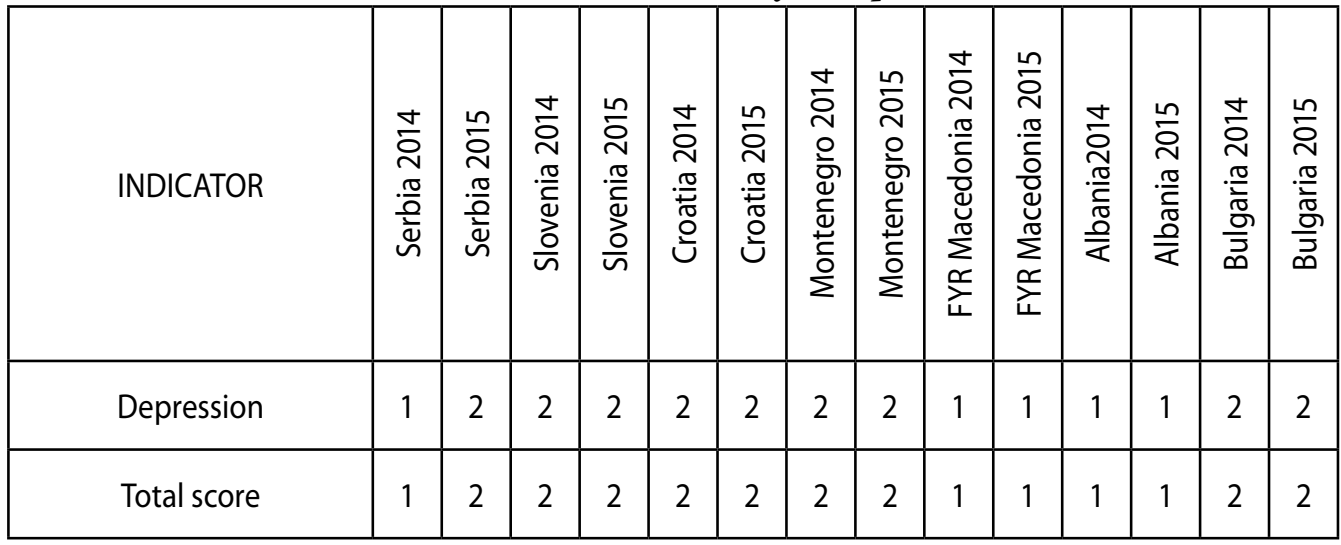

Legend:1. weak; 2. good or uncomparable; 3 . great

Ministry of Health of the Republic of Serbia, the republic expert committee for creation and implementation of the best practises guidelines, published a National guide to good clinical practise in diagnosing and treating depression, through the "DILS" (Delivery of Improved Health Services) project of the Serbian Ministry of Health.

Considering the indicators regarding depression for 2014 and 2015, the guide was widely applied and thus contributed to the significant progress Serbia has made in 2015 (2), which helped reach the same level as Slovenia, Croatia, Montenegro and Bulgaria, while surpassing Macedonia and Albania, in regards to this indicator. 
Group 4. - Range and reach of services The fourth set of indicators evaluatedrange and reach of servicesthrough the following indicator:

1) Long term care for elderly

Table 5. Range and reach of long term care services provided in 2014 and 2015

\begin{tabular}{|c|c|c|c|c|c|c|c|c|c|c|c|c|c|c|}
\hline INDICATOR & 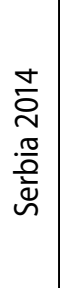 & 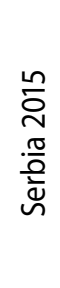 & 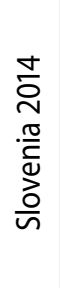 & 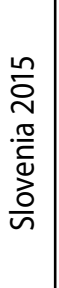 & 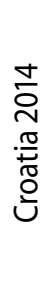 & 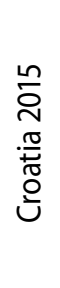 & 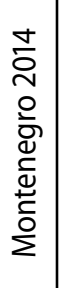 & 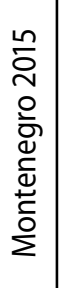 & 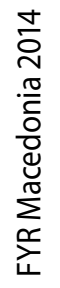 & 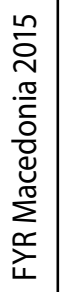 & 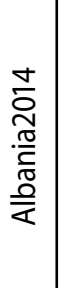 & 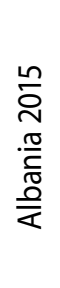 & 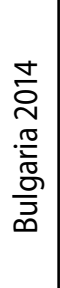 & 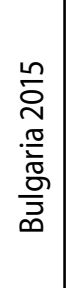 \\
\hline Long term care for elderly & 1 & 1 & 2 & 2 & 1 & 1 & 2 & 2 & 1 & 1 & 1 & 1 & 1 & 1 \\
\hline Total score & 1 & 1 & 2 & 2 & 1 & 1 & 2 & 2 & 1 & 1 & 1 & 1 & 1 & 1 \\
\hline
\end{tabular}

Legend:1. weak; 2. good or uncomparable; 3. great

Long-term health care for the elderly includes a wide range of assistance to the elderly with daily activities over a long period of time in order to assist them and to ensure them a higher quality of life.

In 2014 and 2015, Serbia recieved a minimum score of (1) when the longterm protection of elderly persons is considered, together with Croatia (1), Macedonia (1) Albania (1) and Bulgaria (1).

Only Slovenia (2) and Montenegro (2) have solved the problem of the longterm care of the elderly in 2014 and 2015. In Serbia, work is being done on opening new and adapting the existing instituions for long-term health care of the elderly, so an improvement of this indicator is expected in the coming years. 
Group 5. - PreventionThe fifth set of indicators evaluated preventionthrough the following indicators:

1) Smoking prevention

2) Alcohol

Table 6. Prevention achieved in 2014 and 2015

\begin{tabular}{|c|c|c|c|c|c|c|c|c|c|c|c|c|c|c|}
\hline INDICATOR & 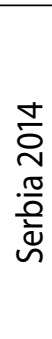 & 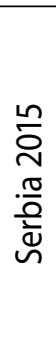 & 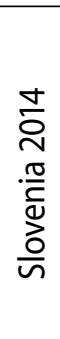 & 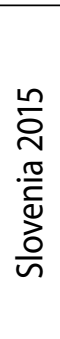 & 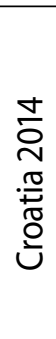 & 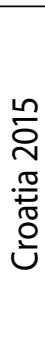 & 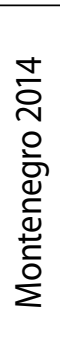 & 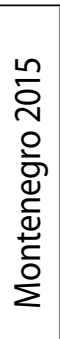 & 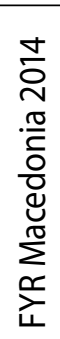 & 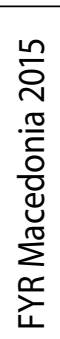 & 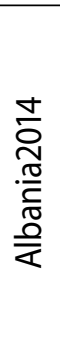 & 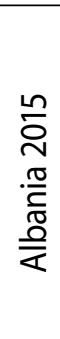 & 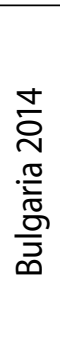 & 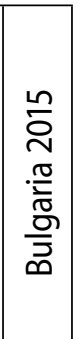 \\
\hline Smoking prevention & 1 & 1 & 1 & 1 & 1 & 1 & 1 & 1 & 1 & 1 & 1 & 1 & 1 & 1 \\
\hline Alcohol & 2 & 2 & 2 & 2 & 2 & 2 & 3 & 3 & 3 & 3 & 3 & 3 & 2 & 2 \\
\hline Total score & 3 & 3 & 3 & 3 & 3 & 3 & 4 & 4 & 4 & 4 & 4 & 4 & 3 & \\
\hline
\end{tabular}

Legend:1. weak; 2. good or uncomparable; 3. great

Smoking prevention has not yielded the expected results in any country in the region in 2014 and 2015 (all of the observed countries were rated with the lowest mark (1)).

The unfavorable situation with this indicator points to a need for more work on a defined range of activities related to the prevention of smoking, as well as a need for introducing new targeted activities, such as working harder on the problem within the community. This would yield better results for the requested indicators, while reducing the harmful effect of smoking on the health of both smokers and non-smokers.

Unlike smoking prevention, prevention of alcoholism is at a good stable level in the surveyed countries in the region. Serbia with 2 points is equal with Slovenia (2) Croatia (2) and Bulgaria (2), while excellent results are also achieved by Montenegro (3), Macedonia (3) and Albania (3).

Group 6. - Pharmaceuticals. The sixth set of indicators was not assesed in this study, as none of indicators had any connections to mental health care drugs 


\section{CONCLUSION AND RECOMMENDATIONS}

The Republic of Serbia, according to the European Health Consumer Index, was ranked 33rd. in 2014 among European countries, with 473 points, while in 2015 was ranked 30 with 554 points.

Mental health care indicators show improvement in 2015 comparing with 2014 year. This ranking and applied parameters, provide clear insight into what is good in health care system of Serbia and what needs to be improved in order to reach the ultimate goal - satisfied and healthy user-consumer of health care system.

The greatest advances in Serbia have been made in 2015 compared to 2014, in the area of the patient rights and their awareness, such as having the right to a second opinion, access to their own medical data, and the fact that a registry of bona fides doctors in Serbia has been created.

Regarding the availability of health services, directly coming to a specialist has been made easier, and the waiting time in emergency cases has been reduced in 2015 compared to 2014.

The improvement of indicators for depression treatment, which through the National guide to good clinical practise in diagnosing and treating depression became available to all general practitioners (and thus enabled them to more easily identify the given problem), represents the most significant progress in terms of mental health care in 2015 compared to 2014.

In order for users of health care in the Republic of Serbia to be healthy and happy with health care system, the following parameters should be improved:

- long term care for elderly,

- activities on prevention and promotion of smoking, and

- activities to reduce adverse treatment outcomes.

\section{Table's Endnotes}

1) WHO (2016): "Mental Health: A State of Well-being", Retrieved May 7, 2016

2) WHO (2016): "Mental Health: A State of Well-being", Retrieved May 7, 2016

3) WHO (2016): "Mental Health: A State of Well-being", Retrieved May 7, 2016

4) Björnberg Arne, Hjertqvist Johan (2015): "Euro Health Consumer Index 2014 Report", Health Consumer Powerhouse, 27.01.2015

5) Björnberg Arne, Hjertqvist Johan (2016): "Euro Health Consumer Index 2015 Report", Health Consumer Powerhouse, 26.01.2016

6) WHO (2014): "European Health for All database" (HFA-DB), Copenhagen,WHO Regional Office for Europe; 2014

7) WHO: http: http://www.who.int/nha/en/

8) Eurostat: http://epp.eurostat.ec.europa.eu; 2014

9) Internet, www.corporatehealthgroup.com 


\section{Literature:}

- Björnberg Arne, Hjertqvist Johan (2015): "Euro Health Consumer Index 2014 Report", Health Consumer Powerhouse, 27.01.2015

- Björnberg Arne, Hjertqvist Johan (2016): "Euro Health Consumer Index 2015 Report", Health Consumer Powerhouse, 26.01.2016

- Eurostat: http://epp.eurostat.ec.europa.eu; 2014

- Internet, www.corporatehealthgroup.com

- WHO (2014): "European Health for All database" (HFA-DB), Copenhagen,WHO Regional Office for Europe; 2014

- WHO (2016): "Mental Health: A State of Well-being", Retrieved May 7, 2016.

- WHO: http: http://www.who.int/nha/en/ 
Prim. mR SC. Med. Periša Simonović

Institut za javno zdravlje Srbije „Milan Jovanović Batut”, Beograd

Doc. DR Milena Gajić-STevanović

Stomatološki fakultet Pančevo, Institut za javno zdravlje Srbije, Beograd

Mr IVAn STEVANOvić

Udruženje „Zdravstveni monitor“, Beograd

\section{EFEKTIVNOST ZDRAVSTVENOG SISTEMA \\ U SRBIJI U 2014. i 2015. I POKAZATELJI ZAŠTITE MENTALNOG ZDRAVLJA}

Svetska zdravstvena organizacija je istakla značaj mentalnog zdravlja tako što ga je uključila u svoju definiciju zdravlja kao: „Zdravlje je stanje potpunog fizičkog, mentalnog i socijalnog blagostanja, a ne samo odsustvo bolesti ili slabosti."Mentalno zdravlje direktno utiče na kvalitet života gradjana kao i na produktivnost privrede. Zbog toga, kako država, tako i preduzeća, imaju interes za dalje unapredjenje u ovoj oblasti. Evropski zdravstveni potrošački indeks (EHCI) predstavlja projekat kojim se od 2006. godine porede $i$ rangiraju zdravstveni sistemi evropskih zemalja, iz ugla pacijenata (potrošača) - korisnika zdravstvenog sistema, sa osnovnim ciljem postavljanja standarda za dobro funkcionisanje $i$ organizaciju zdravstvene zaštite. Procena zdravstvenih sistema se radi na osnovu unapred odredjenih četrdeset osam pokazatelja, rasporedjenih u šest grupa. Cilj ove studije je bio da se proceni stanje zaštite mentalnog zdravlja u Srbiji u 2014. i 2015. godini iz perspektive evropskog zdravstvenog potrošačkog indeksa i predlože preporuke za njeno unapređenje i funkcionisanje u skladu sa evropskim normama i standardima. Republika Srbija, u skladu sa Evropskim zdravstvenim potrošačkim indeksom, je sa 473 boda zauzela 33. mesto u 2014. godini među evropskim zemljama, dok je u 2015. godini sa 554 bodova bila rangirana 30-ta. Pokazatelji mentalnog zdravlja pokazuju poboljšanje u 2015. godini u odnosu na 2014. godinu.

Ključne reči: zdravstveni sistem, Evropski zdravstveni potrošački indeks, mentalno zdravlje 